\title{
The Non-Take-Up of Health and Social Benefits: What Implications for Social Citizenship?
}

\section{Le non-recours aux prestations sociales et sanitaires: quelles implications pour la citoyenneté sociale?}

\section{Nichtbezug von Gesundheits- und Sozialleistungen: Was sagt er über die Grenzen des Wohlfahrtstaates aus?}

Barbara Lucas*, Jean-Michel Bonvin**, and Oliver Hümbelin***

The sociology of welfare tends to focus on welfare regimes, welfare institutions or welfare beneficiaries. However, since the 1960s a specific stream of literature highlights the phenomenon of non-take-up of welfare benefits in the European context (for a literature review, see Kerr 1982; van Oorschot, 1991; Daly 2002; Warin 2006; Eurofound 2015). Indeed, many people eligible for welfare benefits, both in the field of health and social care, do not receive them. This phenomenon questions both the conditions of access to social benefits and their adequacy or even legitimacy when some people prefer not to claim their rights. Understanding the reasons accounting for non-take-up is therefore essential for the design of adequately inclusive social protection frameworks, especially given that non-take-up is becoming salient and reaching policy agendas, including in Switzerland.

In the wake of both conservative and liberal criticisms, the transformation towards a less generous and more restrictive welfare state contributed to creating a gap between the citizens and the social institutions. However, both the political obsession with budget saving and the focus on fraud kept this gap in a blind spot. With the coronavirus crisis, which strongly hit in 2020, media and politics have given a new attention to the non-take-up issue. Social inequalities are growing, including in Switzerland, where people with lower income are most affected (Martinez et al. 2021). In the context of this new social emergency, the social and economic precariousness of numerous categories of the population were put in the spotlight. The relevance of social rights has thus gained legitimacy.

$1 \quad$ We are grateful to Felix Bühlmann and Olivier Giraud for their useful remarks on a first version of this introduction.

* Haute école de travail social Genève, Hets (HES-SO), CH-1211 Genève 4, barbara.lucas@hesge.ch

** Université de Genève, Département de sociologie, CH-1211 Genève 4, jean-michel.bonvin@unige.ch

*** Bern University of Applied Sciences BFH | Social Work, CH-3012 Bern, oliver.huembelin@bfh.ch 
Against this background, this special issue highlights the central role of potential beneficiaries of social rights in the definition and characterization of the contemporary welfare states and, ultimately, in the experience and meaning of social citizenship. To paraphrase Procacci's (1996) interrogation about the poor, one may ask whether the people placed by circumstances in the ambit of the welfare state protection, yet without benefitting from it, are citizens in their own right. If the answer to this question is yes, then attention must be paid to what the non-take-up of social benefits - as a silent voice - tells about the reconfiguration of the relations between citizens and the state. Specifically, what does non-take-up say about the aims of social policies and the way they are received by the different groups of people concerned? What does it say about the underlying norms of social policies and the ways these norms are incorporated or contested by the targeted populations? What does it say about the public service and its hospitable or inhospitable character?

To introduce the reader to the topic of non-take-up, we start with a short overview of the state of the research in Western societies, with a special focus on Switzerland. We then present the main types and reasons of non-take-up (section 1). In section 2, we develop the agenda further and describe three contributions of non-take-up analysis and their implications for our understanding of social citizenship: the importance of temporal dimensions of non-take-up, the central place of the recipients of social policies and the need for more systemic analyses of non-take-up. We conclude in section 3 on how the individual contributions of this special issue develop this view.

\section{Non-Take-Up, a Developing Research Agenda}

\subsection{Prevalence and Awareness of Non-Take-Up in Western Societies}

Little attention has been paid to non-take-up for a long time (van Oorschot 1991). Van Oorschot's international comparison showed that - back in the early 1990s only researchers in Britain, the Netherlands and West Germany worked on the topic while other countries neglected the subject. However, since his wake-up call a solid body of literature has emerged investigating the scope of the phenomenon in several countries. To date it is common sense that non-take-up is present in relevant scope in all OECD countries (Hernanz et al. 2004) and EU member states (European Commission 2006; Eurofound 2015) ranging from rates between 20 to $80 \%$ depending on the type of benefit and the country of research. Several studies advance the country specific research agendas in Austria (e.g. Fuchs et al. 2020), Belgium (e. g. Van Mechelen and Janssens 2017), Finland (e. g. Bargain et al. 2012), Canada (e. g. Daigneault and Macé 2020), France (e.g. Rode 2009; Warin 2016), Greece and Spain (Matsaganis et al. 2010), Germany (e. g. Becker and Hauser 2005; Bruckmeier and Wiemers 2018; Harnisch 2019) and the Netherlands (e. g. Rei- 
jnders et al. 2018). While this list is not exhaustive it shows the existence of a lively scientific discourse around the topic of non-take-up. This does not (yet) necessarily translate into policy making. Today most Western countries do not even monitor non-take-up rates on a regular basis. It is only recently that voices got louder in favor of implementing proper statistics to observe developments on a regular basis (see for example the cases of $\mathrm{UK}^{2}$ and France ${ }^{3}$ ).

In Switzerland the topic was recently brought to the national agenda. An interpellation called the government to investigate the scope of non-take-up in social assistance ${ }^{4}$. Arguing that in Switzerland social assistance is provided on the sub-federal level, the federal government refused to address the issue. In fact, there are no official figures on non-take-up. This gap ought to be filled with studies carried out by scholars and academic researches. Compared to the literature produced in other European countries, studies on non-take-up in Switzerland are still limited but seem to be growing. There are several studies addressing non-take-up of social assistance. First estimations were conducted based on the national study on quality of life and poverty in Switzerland (Leu et al. 1997; Fluder and Stremlow 1999). Estimates ranged from $45 \%$ to $86 \%$. It took nearly 15 years until Crettaz et al. (2009) brought back the topic of non-take-up by comparing poverty statistics with social assistance statistics. They found that $28 \%$ of those below the poverty line did not take up any cash benefits. More recently Hümbelin (2019) used linked tax data to study non-take-up of social assistance. He came up with a similar estimate and showed that there are substantial regional differences in non-take-up that can be related to political milieus. Fluder et al. (2020) proposed to use linked tax data to include non-take-up as an important key figure of a comprehensive Swiss poverty monitoring.

All these studies show that non-take-up rates of social assistance are substantial. Nevertheless, more studies are needed to follow its development and to understand its causes and consequences.

Qualitative research supported this endeavor in Switzerland and provided valuable insights. Rossini and Favre-Baudraz (2004) were the first to study non-take-up of the Swiss welfare benefits from the perspective of individuals by analysing 165 biographies of people experiencing poverty in Switzerland. They drew attention to the fact that targeting social benefits could enhance social exclusion. More recently Lucas et al. (2019) explored the reasons of non-take-up of various social benefits in the canton of Geneva by interviewing families living in precarious conditions. With regard to social assistance, results confirm problems of access, aggravated by a perceived inhospitality of the social service. Above all, most participants strongly reject the perspective of becoming a recipient of social assistance. Here, non-take-up

2 Income-related benefits: estimates of take-up: financial year 2018 to 2019 - GOV.UK (www.gov. uk) (12.03.2021).

3 Le non-recours aux prestations sociales - Mise en perspective et données disponibles - Ministère des Solidarités et de la Santé (solidarites-sante.gouv.fr) (12.03.2021). 18.4227 | Nichtbezug in der Sozialhilfe | Geschäft | Das Schweizer Parlament (12.03.2021). 
appears as a way to put one's values (work, independence, bravery) into practice or as a mark of disinterest for the content of the public offer (Lucas 2020).

Since social assistance is the last safety net in Switzerland, it is important to know how many people are living below the poverty line and to understand the reasons why they do not seek government support. Therefore, it is no wonder that most studies on non-take-up focus on social assistance. Furthermore, little is known about the extent to which other means-tested benefits such as supplementary benefits or subsidies for a cost reduction of health insurance premium are not taken up. It is thus not clear if access to insurance-based benefits like the unemployment benefits might also be hampered. Rosenstein (2018) argues that while the recent reforms of the disability insurance led to a decline of cases, these same reforms also enhanced the risk of non-take-up of disability benefits. It is very likely that nontake-up occurs in other parts of the Swiss welfare system as well. More research is needed to address non-take-up in general, to understand access and hurdles of the Swiss social security system.

Finally, there are signs that full access to the Swiss healthcare system is not granted to all residents, even though Switzerland introduced in 1994 the mandatory health insurance system. Based on interviews with people without health insurance, Roduit (2020) was recently able to shed light on the reasons of such non-take-up (lack of information, difficulties to pay, but also professionals' attitudes or insurance practices) as well as the implications for their access to health care. In particular, she showed how this access is regulated in the health care system by informal sorting processes of people asking for health care.

In this context Remund et al. (2019) question the success of Swiss healthcare policies by observing differences in life expectancies across socioeconomic groups that increased in the last decades. According to the authors, this may reflect unequal access to preventive care due to high out-of-pocket expenses in the healthcare system. In the same vein, a study conducted by Kilchenmann et al. (2017) shows that the out-of-pocket costs have behavioural effects on the use of medical services. People with low income, poor ability to pay and a high share of self-pay healthcare costs tend to forgo benefits more often. The authors estimate that only a small percentage of the Swiss population ( $1 \%$ ) is affected by this form of non-take-up. This said the Swiss Health Observatory (OBSAN 2020) points to a higher share of the Swiss population not receiving necessary health services for financial reasons (between 3 to $5 \%$ ).

All in all, the above review shows that non-take-up of social and healthcare services occur across societies. At the same time, research interest for non-take-up is on the rise and the body of literature has steadily grown these last years. 


\subsection{Types and Reasons of Non-Take-Up, What Do We Know So Far}

Strictly speaking non-take-up refers to the situation where eligible individuals do not take up a benefit they are entitled to (van Oorschot, 1991). However, since the development of the client-focused Kerr model (Kerr 1982), scholars soon understood non-take-up in a broader context.

Today it is common sense to further distinguish between different types of non-take-up (Goedemé and Janssens 2020), to be able to grasp its meaning and causes. First, Van Oorschot (1995) distinguishes between primary and secondary non-take-up. The former refers to the situation where an eligible individual does not claim her benefit (no matter if intentionally or not). The latter points to the situation where individuals start the application, but end up not receiving it, despite being eligible. Van Mechelen and Janssens (2017) suggest adding tertiary non-take-up as a situation in which vulnerable persons are not entitled to a social provision due to eligibility rules. This is particularly important because it sheds light on vulnerable immigrants who meet financial eligibility criteria, but do not have access to any benefits because they lack civil rights.

Warin (2016) develops van Oorschot's reflections further by identifying four types of non-take-up:

, non-knowledge occurs if eligible individuals are not aware of the existence of a certain benefit.

non-request occurs if eligible individuals know a benefit, but do not claim it. , non-receipt occurs if eligible individuals request the benefit, but do not obtain it.

- non-proposal finally occurs when a benefit is not offered, despite the applicant's eligibility.

The first two types correspond to van Oorschot's idea of primary non-take-up, while the third aligns with the concept of secondary non-take-up. The fourth situation, where providers do not propose a benefit to potential claimants, adds a new perspective, so far less well studied (Observatoire de la santé et du social de Bruxelles 2017). Using this typology, it becomes evident that non-take-up might occur because of (missed) actions on the individuals' and/or providers' side.

When turning to the international literature there are many reasons and factors that have to be considered to understand non-take-up (Hernanz et al. 2004; Eurofound 2015; Van Mechelen and Janssens 2017). A helpful overview identifies four major determinants of non-take-up (Hernanz et al. 2004):

1. Lack of information: potential beneficiaries do not have adequate information or fail to understand their rights, or how to claim benefits (see for example Daponte et al. 1999).

2. Social and psychological factors: Especially if benefits are negatively connoted individual and social barriers seem to hamper take-up. The literature often 
refers to stigma-effects (Moffitt 1983; Baumberg 2016) or an effect of individual and social norms (Hümbelin 2019).

3. Administrative requirements: Some studies show that the process of applying in itself discourages people from claiming benefits due to the complexity and number of administrative requirements (Van Oorschot 1991; Van Oorschot 1998; Van Oorschot 2002; Currie 2006; Neuenschwander et al. 2012).

4. Pecuniary determinants: The expected amount of benefits and the degree of need might affect non-take-up behaviour too (Riphahn 2001; Bruckmeier and Wiemers 2012).

While this list serves as a first orientation, it is not exhaustive. The empirical situation is often more complex. This said this theoretical understanding of non-take-up goes one step further with Van Mechelen and Janssens (2017). Building on Van Oorschot's work (1996) they distinguish between factors related to the policy design, the administration, and the client, thus suggesting a sytemic view on non-take-up. The policy design essentially determines the benefit levels and eligibility criteria that can affect take-up rates both directly and indirectly. At the administration level, researchers study aspects like the degree and quality of information provision or the user-friendliness of the application procedure. At the client level, one must consider procedural aspects as well as psychological and social factors.

\section{Implications of the Analysis of Non-Take-Up for the Study of Welfare States}

On the whole, non-take-up studies still appear quite disparate. They focus on a variety of services, in different national contexts, and point out a series of (sometimes contradictory) causes. Non-take-up can thus still be qualified as an "academic puzzle" (Currie 2006). However, we can identify some stepping stones towards a more integrated theory of non-take-up. In this section, we highlight three of these stepping stones, which sharpen our understanding of social citizenship and therefore help us develop a critical sociology of the welfare state. Rather than claiming an exhaustive overview, we intend to suggest new research directions with which the five papers of this special issue engage.

\subsection{Taking Full Account of the Time Dimension}

Various research results indicate that non-take-up of social benefits is not necessarily a definitive or permanent decision or situation. It can be punctual or temporary. Moreover, non-take-up can occur at different moments of the interaction process between potential recipients and social institutions. Time and timing are thus essential in grasping the mechanisms and dynamic of non-take-up, even more so when welfare states themselves are changing and their legitimacy may be accordingly questioned. 
First, researches emphasize the dynamic character of non-take-up. As a matter of fact, non-take-up was early conceived as a moment in the process of claiming. In his groundbreaking contribution, Kerr (1982) builds on pioneering works explaining non-take-up in the context of the British welfare state. By developing a sequential model, he integrates the different factors - previously identified as causes of nontake-up - into a single theory of decision-making. In this model, individuals are supposed to successively achieve six thresholds to claim a benefit (see Rosenstein's paper in this focus issue for a presentation of this model).

However, claiming for a benefit is not the end of the story since non-takeup can also occur after an individual has submitted an application (Van Oorschot 1998). Indeed, the administration can still unrightfully reject a claim and a person may still renounce to her application due to administrative burdens. Moreover, the process of claiming can be accelerated by disruptive events - trigger events - such as life events or new information about the program. On the opposite, frictional non-take-up refers to a situation where benefits are paid with considerable delay by the administration. Hence, the distinction between permanent non-take-up and temporary (or delayed) non-take-up is now well admitted. In order to explain such delay, researchers in behavioural economics have pointed to a series of reasons why people procrastinate the decision or why people do not move smoothly from decision to action (Baicker et al. 2012)

Second, the temporal dimension has been integrated as a component of the non-take-up phenomenon. Indeed, the way beneficiaries integrate time and temporality in the perceptions of their situations plays a significant role in their evaluation of the situation. For instance, people's perceptions of the permanent or temporary character of their precariousness impact their choice of not claiming for benefits. In this vein, most studies confirm the strong correlation between non-take-up and the duration of the entitlement (Van Mechelen and Janssens 2017).

In a life trajectory perspective, previous experience of migrants with the state, be it supportive or coercive, as well as individual past experiences with social services can contribute to explain non-take-up. On the other hand, future projections matter. Qualitative research (Lucas et al. 2019) has shown how people experiencing social precariousness give meaning to this situation in relation with their respective life courses and consider claiming for social benefit in this context. Perceiving one's social status as part of an upward or downward path gives rise to different types of non-take-up.

Thus, research results point to the importance of taking into account the time dimension in order to understand non-take-up. In this perspective, further investigation is needed to deepen our comprehension of non-take-up as a dynamic phenomenon, as well as to shed light on its intrinsic temporal dimension. Several tracks could be explored.

First, the focus on the causes of non-take-up - in the context of the process of claiming - has somehow left the consequences of non-take-up in a blind spot. Shift- 
ing the attention to the consequences - as an additional step, after the "claiming" stage and the "application" stage - also echoes the policy feedbacks research program, which requires considering public policies not only as means to reach predefined objectives, but as processes likely to modify the political field (Spire 2016). Exploring the consequences of non-take-up can contribute to show how public measures produce changes in social practices or representations.

Second, the dynamic analysis of social inequalities could also benefit from more longitudinal approaches of take-up and non-take-up of social benefits. In line with the theory of cumulative disadvantage in life course studies, the role of non-take-up in the reinforcement of inequalities could also be explored further (Dannefer 2003).

Third, more dynamic analyses of non-take-up along the whole social access pathway could contribute to a better understanding of the impact of welfare reforms at a more local level. In the context of the spatial rescaling of European welfare states (Keating 2021) we witness a transfer of tasks and funding of social solidarity from national to regional or local levels. The resulting reorganizations of territorial social systems may impact non-take-up.

\subsection{Putting the Capable Social Policy Recipient Center Stage}

As an object of research, non-take-up focuses on the population targeted by social policies. As is argued elsewhere (Warin and Lucas 2020), non-take-up is a powerful analytical category in the perspective of critic, in particular because it introduces the recipient as a paradigm in the context of welfare state research. Whatever the issue or the theoretical and methodological approaches, recipients of social policies are always central to the latter questions.

However, the way recipients have been theoretically constructed differs. In many existing studies, non-take-up is explained by a lack of capacity and/or resources of some categories of people that prevent them to fully access their rights. Such lack of capacity is first attributed to social factors, since the most disadvantaged social categories are considered as the most at risk of non-take-up due to a lack of cultural or social resources. Catrice-Lorey (1976) discussed this as a "socio cultural handicap" experienced by low socio-professional groups. As she pointed out, some beneficiaries "are less able to use social protection systems, because they are less informed about what they are entitled to, and more bewildered by the administrative game" (Catrice-Lorey 1976, in Warin 2016, 195; our translation). In the same vein, the risk of non-take-up related to the lack of digital autonomy in a context of growing digitalization of social services has also been recently explored (Revil and Warin 2019) 5 .

5 Apart from the risk of non-take-up for the most vulnerable people, the authors insist on the risk of digitalization for the prevention of non-take-up, when digitalization eliminates possibilities of interaction. 
This idea of shortcomings is also inherent in the way the notion of "costs" is used in non-take-up studies. Based on the premise of a rational cost-benefit calculus in the process of claiming, many quantitative works on non-take-up integrate information costs, process costs as well as stigma viewed as social costs in their explanation model. However, empirical evidence on the reasons of non-take-up are mostly gathered in an indirect way, using a number of variables as proxies (Van Mechelen and Janssens 2017) ${ }^{6}$. Hence, the impact of the lack of capacity of specific categories of population is often more presumed than demonstrated. More direct data has been collected through surveys (population surveys or asking services users) or through the targeted population in field experiments but it is difficult to pin down the groups of people that are less likely to take up a benefit. Some situations, like social isolation, migration status or the absence of a fixed address have been identified as factors contributing to non-take-up (Eurofound 2015).

Recent research in behavioural economics strongly contributes to a renewal of this incapacity framework by focusing on the behavioural barriers to claiming social benefits. Interestingly, this work emphasizes the limits of the individual rationality presumed in cost-benefits analysis of non-take-up, mobilising psychological factors to explain why some people do act "against their interests". In this perspective, poverty is considered to impede cognitive functions, because the situation of poverty consumes much of the mental resources of the people concerned. As a consequence, "the poor behave in a less capable way" (Mani et al. 2013, 976).

In contrast to this dominant and somehow debilitating approach to recipients of social policies (understanding non-take-up as the outcome of a lack of resources or as a consequence of psychological barriers), the work of Warin and colleagues (Warin 2016) represents an alternative perspective that frames non-take-up in the context of an active citizenship, in the sense of "constructive social participation" (Smith et al. 2005). Paying particular attention to the type of non-take-up they call "non-request" (see definition above) allows them to reflect on both democracy and active citizenship. Indeed, they explore the reasons for not making a claim that go beyond shortcomings, like disinterest, mistrust, or perceived unsuitability for the individual needs (Mazet 2014). Interestingly, the potential beneficiary is considered to be able to contest the actual relevance of the public offer - regardless of her socioeconomic position. Hence, non-take-up involves a discussion about needs' definition and thus acquires a political dimension.

In the continuity of this approach, research on non-take-up is being developed which focuses on the reception of social policies (Revillard 2018), an approach that essentially draws from the sociology of culture and from legal consciousness studies. This work enlarges our understanding of citizenship as a lived experience (Lister 2007; Kallio et al. 2020). On the basis of a reflection about the ineffective-

6 For instance, socio-demographic characteristics are used as proxies to estimate the level of cost that comes with claiming (which refer to information costs or administration costs). 
ness of law, scholars are called to seriously take into consideration how the law is perceived and appropriated or contested by the people who must comply with it. For Sarat (1990), for instance, poor welfare beneficiaries have a different experience of law than other groups of society. For them, the law is not an abstraction, it is a manifestation of power that has a concrete impact on their lives. In such a context, non-take-up can be understood as an act of resistance (Tabin and Leresche 2019).

From a reflection on shortcomings or cost-benefit calculus, we are brought to an investigation about the resources and capacity of social policies recipients and about the meaning of non-take-up in the context of a stratified society. In this line of scholarship, Vial showed how the dimension of identity is at the heart of the experience of poorly qualified young people's non-take-up. He also explains how non-take-up reflects the distant, even conflicting relationships that young people build with the public sector (Vial 2020). Another recent qualitative research (Lucas et al. 2019) has shown in this vein that "voluntary" non-take-up happens to be strongly influenced by gendered strategies: men and women experiencing social precariousness differently anticipate their future social status. Thus, men's reticence to claim financial benefits is about avoiding social disqualification. In contrast, women link non-take-up to the inadequacy of financial welfare schemes: their core need revolves around acquiring social qualification. In this respect, financial benefits alone are of little help. What they would actually need is qualifying, professional training, better conditions for balancing family and work life, to ultimately emancipate themselves from gendered patterns of domination.

These approaches partly resonate with the works on the "culture of poverty", which described attitudes of mistrust, withdrawal and criticism of the welfare state by poor communities in the 1960s (Lewis 1963). They contribute to a form of renewal of this research stream that was put on the back burner for several decades, due to the recuperation of the culture of poverty concept by the conservative political parties, referring to a culture of dependence on the state (Duvoux 2010).

This new conception of the recipient of social policies has also significant methodological implications. Indeed, up to now, most research tried to explain take-up or non-take-up using quantitative methodologies. However, in order to get a better understanding of non-take-up, from the perspective of the recipients of social policies, scholars are called to develop more qualitative research. Biographical interviews, for instance, can greatly contribute to this comprehensive sociology of the reception in the field of social policies (Revillard 2017).

\subsection{Moving Towards a Systemic and Relational Approach}

Non-take-up, as a sociological object, sheds light on the limits of efficient and equitable contemporary social policies in the context of changing social and economic conditions. As such, the research on non-take-up highlights the shortcomings of the "inclusive citizenship" project (Lister 2007) and allows identifying its causes. To 
unfold such potential of non-take-up studies for a critical analysis of social citizenship, a systemic and relational approach is needed.

Indeed, it is now well admitted that the reasons for non-take-up are to be found at different analytical levels: the macro level (social norms and welfare design); the meso level (organizations, including public administrations) and the micro level (sometimes called the "client level" or "street level" bureaucracy). This multi-level approach to non-take-up has produced powerful results. However, most studies have had difficulties in holding together these different levels of analysis into an integrated approach. This has often resulted in a kind of disconnection between agency and structure, or an excessive emphasis on one term at the expense of the other.

On the one hand, non-take-up has been attributed to the individuals and their shortcomings or understood in the context of the sociology of culture (the so-called primary non-take-up); on the other hand, and partly as a reaction to this first approach, other authors insisted on the impact of the type of welfare states and the functioning of their administrations, thus shedding light on secondary and tertiary non-take-up (Van Oorschot 1996). More specifically, this second stream of the nontake-up literature has resulted in a powerful critique of recent social policy reforms.

At the macro level of the welfare design (and its underlying norms), targeting social benefits are said to increase both complexity and control therefore generating new barriers of access. The higher level of conditionality of means-tested benefits risks automatically translating into "administrative burdens", but the opacity of such administrative burdens can also facilitate their use as forms of "hidden politics" (Moynihan et al. 2014). Targeting has also been considered to increase welfare stigma (Waxman 1983; Spicker 1984). For instance, early work on welfare stigma showed how black minorities in the United States (especially poor mothers) hardly participated in social programmes, yet designed for them, due to a strong stigma which expressed a form of "racialization" of the welfare state and poverty (Warin 2012).

Moreover, the increasing activation of policy recipients (in the 1980s in the USA and in most European countries in the 1990s) has been said to generate nontake-up. Activation refers to the promotion of employment of welfare recipients. It is implemented in particular in unemployment and disability insurances, as well as social assistance. The legitimacy of such activation policies is based on their aim to promote social inclusion, but their impact - including on social citizenship - still needs to be clarified (Barbier 2009; Bothfeld and Betzel 2011). Indeed, in this framework, benefit receipt is subordinated to a number of behavioural conditions, framed by incentives and sanctions. Hence, activation may paradoxically produce new forms of exclusion through non-take-up, mainly through an increase of stigma (for instance Yaniv 1997; Baumberg 2016) or access biases in participation especially for migrants and in some cases, for low-skilled people (Bonoli and Liechti 2018). However, empirical data on the effect of activation on individuals' lives and experi- 
ence, and more particularly on the different types of non-take-up it can generate, are still scarce.

The connections between welfare design and other regulatory domains can produce non-take-up as well. More particularly, the naturalization or residence permit renewal procedures play a role in the distance that these populations maintain with social services (Cattacin and Naegeli 2014). In Switzerland, the federal law on foreigners makes family reunification and the renewal of residence or settlement permits conditional upon not being permanently dependent on social assistance. In this context, recent studies based on interviews with people living precariously and with non-permanent residence status in the canton of Geneva confirmed that the revocability of the right of residence is an element likely to produce non-take-up (Lucas et al. 2019; Bonvin et al. 2020).

At the meso level of organizations, research on non-take-up sheds light on the role of gatekeepers in public organizations. Brodkin and Majmundar denounced an "administrative exclusion" referring to situations "when organizational practices (both formally prescribed and informally created), rather than substantive status or individual preference, affect participation in public programs" (Brodkin and Majmundar 2010, 828-829). In Switzerland, Neuenschwander et al. (2012) showed, for example, that the type of non-take-up varies according to the type of admission procedure used by local social assistance services. In the health care system, the reflection on equity in the context of users' growing diversity is well advanced. Among other standards, an "access equity standard" has been proposed to encourage health care organizations to address the identified barriers in access and utilization of the services (Cattacin et al. 2013).

At the micro level, the role of the professionals in the administrations has been pointed out. For example, mistakes made by agents are identified as causes of nontake-up (Warin 2016), as well as "bureaucratic hassle" (Van Oorschot 1996) and different informal practices producing "discouragement" (Bennett 1995; Brodkin and Majmundar 2010). However, social administrations, particularly proximity services, can also play a role in the social identification of the most isolated and deprived people (Dubois 2015) and contribute to their empowerment. This is particularly the case for women, who can find in the context of their relations with social services the means for a form of emancipation (Siblot 2006). In the end, those professionals ${ }^{7}$ have an ambivalent role: on the one hand, they generate non-take-up; on the other hand, they appear as decisive actors in the prevention of non-take-up (Lucas et al. 2019).

Hence, non-take-up literature contributes to discuss the decline of universalism in favour of an increased targeting of social benefits and the activation of recipients at the expense of income protection. However, the precise social mechanisms that

$7 \quad$ This perspective can be extended to the volunteeers and to the different public or private organizations that constitute the local social network. 
relate such institutional changes to non-take-up still must be explored further. Moreover, the upcoming challenge is now to investigate the interplay between the different levels, in the sense of a systemic or relational approach to non-take-up, and how this interplay can have an impact on the take-up or non-take-up of benefits. Such a relational approach appears as the key to an in-depth examination of social citizenship through the lens of non-take-up.

\section{Contributions of the Special Issue}

Authors in this issue contribute to this emerging research agenda by a) emphasizing the temporal dimension of non-take-up, b) supporting a view of the recipients as capable and critical agents, and c) advocating for a systemic and relational approach to non-take-up that sheds light on its implications for social citizenship.

Willke argues that moving beyond traditional rational choice explanations and stigma approaches to non-take-up could open new perspectives. He advocates adopting a relational perspective emphasizing how the gap between "institutional norms of normality" and individual living situations may generate various forms of non-take-up. He explores this relational hypothesis through three complementary lenses. First, he argues that coping strategies with few financial resources might influence non-take-up since non-take-up households often feel less financially stressed than recipients despite having comparable resources. Second, he considers that the extent to which previous achievements are acknowledged within institutional norms and devices (e.g. social insurances vs. social assistance and means-tested benefits) also impacts the likelihood of non-take-up: the less people feel their previous achievements are recognized by a program, the more they are likely to forego these benefits. Third, the temporality of benefit receipt depends on the perception of the need duration, which in turn influences non-take-up: benefits are less attractive if the need is perceived as short-term. In all three cases - coping, acknowledgement, temporal perspective - non-take-up is considered in a relational perspective at the crossroad between institutional norms and individual situations and expectations. This analytical scheme is applied to the old-age basic income support in Germany, using the SOEB database. Empirical analysis shows the importance of the coping and temporal mechanisms while calling for further research with respect to acknowledgement. The paper also underlines the lack of adequate data to investigate non-take-up and advocates integrating indicators documenting the reasons for non-take-up within existing databases, as well as including the relational framework in qualitative studies.

Mallet and Garcia focus on secondary non-take-up, i.e. situations in which eligible people are turned away by street-level bureaucrats (SLBs) in charge of implementing public policies. Their paper examines the specific situation of Latino 
immigrants in this respect, investigating in-depth the three case studies of New York, Madrid and London. They thus show how SLBs' behaviours, to some important extent shaped by the welfare context in each country and locality, impact individual perceptions about their eligibility and, consequently, the likelihood of non-take-up. Prejudice from social providers is identified as a leading driver of secondary non-take-up, where the cumulative and intersectional levels of perceived prejudice - immigration status, ethnicity, class and gender - are emphasized in all three investigated cases, although they take different forms in each setting. While it relates more strongly to class in New York (due to SLBs' prejudice against benefit recipients), it seems to be directed mostly against immigrants in general in London (perceived as abusing a generous welfare state) and driven by ethno-racial reasons such as skin colour in Madrid. The originality of the paper is to explore these issues "from below", i. e. through qualitative interviews with Latino immigrants themselves, showing how recipients perceive their interactions with social service providers and in what way SLB's discretionary power impacts these perceptions, potentially resulting in non-take-up. Here too, a relational perspective to non-take-up is adopted, where the interplay between the local welfare system level, the organizational level and the individual level is at the center of attention.

Revil emphasizes the implications of involuntary non-take-up for healthcare. She convincingly argues that such experiences of non-take-up may undermine the perceptions of the social and health system, resulting in sharp criticisms of what the state chooses to offer in terms of social and health services. She thus shows how involuntary non-take-up may produce voluntary and deliberate non-take-up where people choose not to claim benefits, relying on a critical perception of the action of the state. Through this process, institutional norms, and more specifically the way they have been experienced in previous occasions, become the incentive behind non-take-up. The paper also documents how such deliberate non-take-ups may go hand in hand with alternatives, i.e. non-institutional practices or "little arrangements". Based on a great variety of research results, the paper begins by shedding light on the deleterious impacts of involuntary non-take-up of healthcare benefits and services, then emphasizes how these effects generate critical views on public action and deliberate and voluntary non-demand, accompanied by alternative coping strategies relying on non-institutional mechanisms. To this purpose, the paper adopts a dynamic perspective on non-take-up, showing how involuntary non-take-up may be transformed into active and so-called "reasoned" non-take-up; it also insists that non-take-up is not passively accepted by people, who prove to be agents able to develop alternative strategies. In this twofold meaning, it goes beyond a static view on non-take-up, showing how it can move from involuntary to voluntary over time, and beyond a passive view of non-beneficiaries, emphasising how they are able to react to non-take-up and develop their own strategies. 
Rosenstein examines the tension between normative institutional expectations and individual situations in the specific case of activation policies for disabled people, and how and why this tension may result in non-take-up. Adopting a relational perspective, the paper shows how these gaps between institutional norms and individual expectations and situations operate at each of the six steps of non-take-up in Kerr's model: by distorting the perception of one's need and eligibility as well as the way one assesses the stability of one's situation, while at the same time impeding access to adequate knowledge about social benefits, feeding inadequate perceptions about claiming processes and the utility of benefits. By so doing, activation undermines the sense of entitlement of potential beneficiaries, thus resulting in various forms of non-take-up. On the basis of an extensive mixed-methods survey, the paper reveals the ambivalence of activation policies, which can generate non-take-up while at the same time insisting on increasing the rate of take-up. More specifically, the author explains in great detail how the acceleration of procedures, the conditionalities imposed on accessing or maintaining disability benefits, the willingness to restrict access to pensions, etc. generate ambivalent effects such as time gaps, autonomy gaps, negative beliefs and feelings and other paradoxical outcomes. The paper sheds light on the importance in investigating non-take-up by connecting how policies are designed and how they are received or perceived by their potential beneficiaries.

Eckhardt grasps the issue of non-take-up from the perspective of those who choose to forego their benefits. Based on extensive narrative-biographical interviews, she reconstructs the various modalities and mechanisms of subjectivation that resulted in non-take-up in three individual case studies. Two main dimensions are emphasized. First, the socialization experiences especially those related to unemployment or previous contacts with welfare offices in one's family (in the line of a so-called administrative cultural capital). Such events significantly impact the way people experience their own encounters with welfare administrations. Second, individual representations of poverty and neediness, more or less related to forms of laziness or undeservingness (i. e. also to different principles of justice), also strongly influence how one positions oneself towards being a benefit recipient. Taken together, these two dimensions offer an account of how and why people differently appropriate welfare norms: while some explicitly and radically refuse them (exit), others try to negotiate them (voice) while still others tend to abide by dominant social norms (loyalty). The variety of attitudes toward the welfare state translates into a corresponding diversity of reasons for not taking up available benefits and services. In this paper, the relational perspective to non-take-up is investigated through the lens of biographical interviews. The paper suggests how a perspective combining Foucault's governmentality and Bourdieu's notions of habitus and capital can offer deeper insights towards understanding the motives underlying non-take-up at the crossroad between individual trajectories and values and institutional norms. 


\section{$5 \quad$ References}

Baicker, Katherine, William J. Congdon, and Sendhil Mullainathan. 2012. Health Insurance Coverage and Take-Up: Lessons From Behavioral Economics. The Milbank Quarterly 90(1): 107-134.

Barbier, Jean-Claude. 2009. Le workfare et l'activation de la protection sociale, vingt ans après : beaucoup de bruit pour rien ? Lien social et politique 62: 23-36.

Bargain, Olivier, Herwig Immervoll, and Heikki Viitamäki. 2012. No Claim, No Pain. Measuring the Non-Take-up of Social Assistance Using Register Data. The Journal of Economic Inequality 10(3): 375-95. https://doi.org/10.1007/s10888-010-9158-8.

Baumberg, Ben. 2016. The Stigma of Claiming Benefits: A Quantitative Study. Journal of Social Policy 45(2): 181-99. https://doi.org/10.1017/S0047279415000525.

Becker, Irene, and Richard Hauser. 2005. Dunkelziffer der Armut. Ausmaß and Ursachen der NichtInanspruchnahme zustehender Sozialhilfeleistungen. Berlin: edition sigma.

Bennett, Susan D. 1995. "No Relief but Upon the Terms of Coming Into the House". Controlled Spaces, Invisible Disentitlements, and Homelessness in an Urban Shelter System. The Yale Law Journal 104(8): 2157-2212.

Bonoli, Giuliano, and Fabienne Liechti. 2018. Good Intentions and Matthew Effects: Access Biases in Participation in Active Labour Market Policies. Journal of European Public Policy 25(6): 894-911.

Bonvin, Jean-Michel, Max Lovey, Emilie Rosenstein, and Pierre Kempeneers. 2020. «La population en grande précarité en période de COVID-19 à Genève: conditions de vie et stratégies de résilience" Rapport final de l'étude sollicitée par la fondation Colis du Coeur, available at: https:// www.unige.ch/sciences-societe/socio/files/6616/0086/7051/Rapport_UNIGE_CdC_2020.pdf [accessed 4 March 2021].

Bothfeld, Silke, and Sigrid Betzelt. 2011. How Do Activation Policies Affect Social Citizenship? The Issue of Autonomy. Pp. 15-36 in Activation and Labour Market Reforms in Europe. Challenge to Social Citizenship, edited by Sigrid Betzelt and Silke Bothfeld. New York: Palgrave Macmillan.

Brodkin, Evelyn Z., and Malay Majmundar. 2010. Administrative Exclusion: Organizations and the Hidden Costs of Welfare Claiming. Journal of Public Administration Research and Theory 20(4): $827-848$.

Bruckmeier, Kerstin, and Jürgen Wiemers. 2012. A New Targeting: A New Take-Up? Empirical Economics 43 (2): 565-580. https://doi.org/10.1057/s41294-017-0041-5.

Bruckmeier, Kerstin, and Jürgen Wiemers. 2018. Benefit Take-Up and Labor Supply Incentives of Interdependent Means-Tested Benefit Programs for Low-Income Households. Comparative Economic Studies 60(4): 583-604.

Catrice-Lorey, Antoinette. 1976. Inégalités d'accès aux systèmes de protection sociale et pauvreté culturelle. Revue française des affaires sociales 30(4): 127-137.

Cattacin, Sandro, Antonio Chiarenza, and Dagmar Domenig. 2013. Equity Standards for Health Care Organisations: A Theoretical Framework. Diversity and Equality in Health and Care 10(4): 249-258.

Cattacin, Sandro, and Patricia Naegeli. 2014. Vulnerable Migrants: Coping Strategies and Multiple Paths to Social Exclusion. Pp. 244-270 in Social Vulnerability in European Cities. The Role of Local Welfare in Time of Crisis, edited by Costanza Ranci, Taco Brandsen, and Stefania Sabatinelli. London: Palgrave Macmillan.

Crettaz, Eric, Thomas Jankowski, Tom Priester, Thomas Ruch, and Lukas Schweizer. 2009. Sozialhilfeand Armutsstatistik im Vergleich. Neuchâtel: Bundesamt für Statistik.

Currie, Janet. 2006. The Take-Up of Social Benefits in Poverty. Pp. 80-148 in Public Policy and the Income Distribution, edited by Alan Auerbach, David Card, and John Quigley. New York: Russell Sage. 
Daigneault, Pierre-Marc, and Christian Macé. 2020. Program Awareness, Administrative Burden, and Non-Take-Up of Québec's Supplement to the Work Premium. International Journal of Public Administration 43(6): 527-539. https://doi.org/10.1080/01900692.2019.1636397.

Daly, Mary. 2002. Access to Social Rights in Europe: Report. Strasbourg: Council of Europe Publishing.

Dannefer, Dale. 2003. Cumulative Advantage/Disadvantage and the Life Course: Cross-Fertilizing Age and Social Science Theory. The Journals of Gerontology Series B: Psychological Sciences and Social Sciences 58(6): 327-337.

Daponte, Beth Osborne, Seth Sanders, and Lowell Taylor. 1999. Why Do Low-Income Households Not Use Food Stamps? Evidence From an Experiment. Journal of Human Resources 34(3): 612-628. https://doi.org/10.2307/146382.

Dubois, Vincent. 2015. La vie au guichet: administrer la misère. Paris: Editions Points.

Duvoux, Nicolas. 2010. Repenser la culture de la pauvreté. La Vie des idées 5(10). https://laviedesidees. $\mathrm{fr} /$ Repenser-la-culture-de-la-pauvrete.html (15.03.2021).

Eurofound. 2015. Access to Social Benefits: Reducing Non-Take-Up. Luxembourg: Publications Office of the European Commission. http://publications.europa.eu/publication/manifestation_identifier/ PUB_KINA23141ENN (15.03.2021).

Fluder, Robert, Oliver Hümbelin, Larissa Luchsinger, and Tina Richard. 2020. Ein Armutsmonitoring für die Schweiz: Modellvorhaben am Beispiel des Kantons Bern. Bern: Berner Fachhochschule.

Fluder, Robert, and Jürgen Stremlow. 1999. Armut and Bedürftigkeit: Herausforderungen für das kommunale Sozialwesen. P. Haupt.

Fuchs, Michael, Katrin Gasior, Tamara Premrov, Katarina Hollan, and Anette Scoppetta. 2020. Falling Through the Social Safety Net? Analysing Non-Take-Up of Minimum Income Benefit and Monetary Social Assistance in Austria. Social Policy \& Administration 54(5): 827-843.

Goedemé, Tim, and Julie Janssens. 2020. The Concept and Measurement of Non-Take-up. An Overview, with a Focus on the Non-Take-up of Social Benefit. https://doi.org/10.5281/zenodo.3876517 (15.03.2021).

Harnisch, Michelle. 2019. Non-Take-Up of Means-Tested Social Benefits in Germany. Working Paper 1793. DIW Discussion Papers. https://www.econstor.eu/handle/10419/201420 (15.03.2021).

Hernanz, Virginia, Franck Malherbet, and Michele Pellizzari. 2004. Take-Up of Welfare Benefits in OECD Countries: A Review of the Evidence. OECD Social, Employment and Migration Working Papers No. 17. OECD Publishing. http://dx.doi.org/10.1787/525815265414 (15.03.2021).

Hümbelin, Oliver. 2019. Non-Take-Up of Social Assistance: Regional Differences and the Role of Social Norms. Swiss Journal of Sociology 45(1): 7-33. https://doi.org/10.2478/sjs-2019-0002.

Kallio, Kirsi Pauliina, Bronwyn Elisabeth Wood, and Jouni Häkli. 2020. Lived Citizenship: Conceptualising an Emerging Field. Citizenship Studies 24(6): 713-729.

Keating, Michael. 2021. Beyond the Nation-State: Territory, Solidarity and Welfare in a Multiscalar Europe. Territory, Politics, Governance 9(3), 331-345. https://doi.org/10.1080/21622671.2020.1742779.

Kerr, Scott A. 1982. Deciding About Supplementary Pensions: A Provisional Model. Journal of Social Policy 11(4): 505-517. https://doi.org/10.1017/S0047279400022558.

Kilchenmann, Christoph, Isabel Reding, Boris Kaiser, Michael Gerfin, and Luzia Zimmermann. 2017. Leistungsverzicht and Wechselverhalten der OKP-Versicherten im Zusammenhang mit der Wahlfranchise. Basel and Bern: B,S,S. Volkswirtschaftliche Beratung and Universität Bern.

Leu, Robert E., Stefan Burri, and Tom Priester. 1997. Lebensqualität und Armut in der Schweiz. Bern: Haupt.

Lewis, Oscar. 1963. Les enfants de Sanchez, trad. française. Paris: Gallimard.

Lister, Ruth. 2007. Inclusive Citizenship: Realizing the Potential. Citizenship studies 11(1): 49-61. 
Lucas, Barbara, Catherine Ludwig, Jérome Chapuis, Jenny Maggi, and Eric Crettaz. 2019. Le nonrecours aux prestations sociales à Genève. Genève: Haute école de travail social et Haute école de santé, HES-SO.

Lucas, Barbara. 2020. Pauvreté cachée: les raisons du non-recours à l'aide sociale. Pp. 113-126 in Almanach Social. Quand l'aide sociale évoluera. Lucerne, Ed. Caritas.

Mani, Anandi, Sendhil Mullainathan, Eldar Shafir, and Jiaying Zhao. 2013. Poverty Impedes Cognitive Function. Science 341(6149): 976-980.

Martinez, Isabel, Daniel Kopp, Rafael Lalive, Stefan Pichler, and Michael Siegenthaler. 2021. Corona and Ungleichheit in der Schweiz - Eine erste Analyse der Verteilungswirkungen der Covid19-Pandemie. KOF Studies 161: 1-29.

Matsaganis, Manos, Horacio Levy, and Maria Flevotomou. 2010. Non-Take Up of Social Benefits in Greece and Spain. Social Policy \& Administration 44(7): 827-844.

Mazet, Pierre. 2014. Analysis of the Non Take-Up of Benefits: A Public Policy Assessment Tool 1. In Service de lutte contre la pauvreté, la précarité et l'exclusion sociale. Bruxelles, Belgium.

Moffitt, Robert. 1983. An Economic Model of Welfare Stigma. The American Economic Review 73(5): 1023-1035.

Moynihan, Donald, Pamela Herd, and Hope Harwey (2014). "Administrative Burden: Learning, Psychological, and Compliance Costs in Citizen-State Interaction". Journal of Public Administation Research and Theory. 25: 43-69.

Neuenschwander, Peter, Oliver Hümbelin, Marc Kalbermatter, and Rosmarie Ruder. 2012. Der schwere Gang zum Sozialdienst: Wie Betroffene das Aufnahmeverfahren der Sozialhilfe erleben. Zürich: Seismo.

OBSAN. 2020. Unterbleiben von Arzt- and Zahnarztbesuchen aufgrund materieller Entbehrung (Alter: 16+) | OBSAN. Monitoringsystems Sucht and NCD (MonAM). 2020. https://www.obsan.admin. $\mathrm{ch} /$ de/indikatoren/MonAM/unterbleiben-von-arzt-und-zahnarztbesuchen-aufgrund-materiellerentbehrung-alter-16 (15.03.2021).

Observatoire de la santé et du social de Bruxelles. 2017. Aperçus du non-recours aux droits sociaux et de la sous-protection sociale en Région bruxelloise. Commission communautaire commune: Bruxelles. https://www.ccc-ggc.brussels/sites/default/files/documents/graphics/rapport-pauvrete/ rapport_thema_fr_2016.pdf (15.03.2021).

Procacci, Giovanna. 1996. Exclus ou citoyens? Les pauvres devant les sciences sociales. European Journal of Sociology 37(2): 323-342.

Reijnders, Mark, Jelmer Schalk, and Trui Steen. 2018. Services Wanted? Understanding the Non-Take-Up of Social Support at the Local Level. VOLUNTAS: International Journal of Voluntary and Nonprofit Organizations 29(6): 1360-1374. https://doi.org/10.1007/s11266-018-00060-w.

Remund, Adrien, Stéphane Cullati, Stefan Sieber, Claudine Burton-Jeangros, and Michel Oris. 2019. Longer and Healthier Lives for All? Successes and Failures of a Universal Consumer-Driven Healthcare System, Switzerland, 1990-2014. International Journal of Public Health 64(8): 1173-1181.

Revil, Héléna, and Philippe Warin. 2019. Le numérique, le risque de ne plus prévenir le non-recours. Vie sociale 28. https://www.cairn.info/revue-vie-sociale-2019-4.htm (15.03.2021).

Revillard, Anne. 2017. «La réception des politiques du handicap. Une approche par les entretiens biographiques ». Revue française de sociologie, 1 (58): 71-95.

Revillard, Anne. 2018. Saisir les conséquences d'une politique à partir de ses ressortissants. La réception de l'action publique. Revue française de science politique 68(3): 469-491.

Riphahn, Regina T. 2001. Rational Poverty or Poor Rationality? The Take-Up of Social Assistance Benefits. Review of Income and Wealth 47(3): 379-398.

Rode, Antoine. 2009. L'émergence du non-recours aux soins des populations précaires: entre droit aux soins et devoirs de soins. Lien social et Politiques 61: 149-158. 
Roduit, Sabrina. 2020. Aux frontières de l'accès aux soins: pratiques de tri et parcours de vie de personnes sans assurance-maladie à Genève. Thèse de doctorat, Faculté des Sciences de la Société, Université de Genève. https://doi.org/10.13097/archive-ouverte/unige:137686 (15.03.2021).

Rosenstein, Emilie. 2018. Activer les publics vulnérables? Le cas de l'Assurance-invalidité. Thèse de doctorat, Université de Genève. DOI: 10.13097/archive-ouverte/unige:102769.

Rossini, Stéphane, and Brigitte Favre-Baudraz. 2004. Les oubliés de la protection sociale ou le non-sens du ciblage des prestations. Lausanne et Fribourg: Editions Réalités sociales.

Sarat, Austin. 1990. The Law is All Over: Power, Resistance and the Legal Consciousness of the Welfare Poor. Yale JL \& Human 2(2): 343-379.

Siblot, Yasmine. 2006. "Je suis la secrétaire de la famille!" La prise en charge féminine des tâches administratives entre subordination et ressource. Genèses 3: 46-66.

Smith, Noel, Ruth Lister, and Sue Middleton. 2005. Young People as 'Active Citizens': Towards an Inclusionary View of Citizenship and Constructive Social Participation. Pp. 159-177 in Young People in Transition, edited by Christopher Pole, Jane Pilcher, and John Williams. Palgrave Macmillan, London. https://doi.org/10.1057/9780230597778_9.

Spicker, Paul. 1984. Stigma and Social Welfare. New York: Martins Press.

Spire, Alexis. 2016. Etat des lieux. Les policy feedbacks et le rapport ordinaire à l'Etat. Gouvernement et action publique 5(4): 141-156.

Tabin, Jean-Pierre, and Frédérique Leresche. 2019. Une critique furtive de l'Etat social. Emulations-Revue de sciences sociales, accessible à l'adresse: https://ojs.uclouvain.be/index.php/emulations/article/ view/tabin (15.03.2021).

Van Mechelen, Natascha, and Julie Janssens. 2017. Who is to Blame? An Overview of the Factors Contributing to the Non-Take-Up of Social Rights. Working Paper 1708. Herman Deleeck Centre for Social Policy, University of Antwerp. https://econpapers.repec.org/paper/hdlwpaper/1708. htm (15.03.2021).

Van Oorschot, Wim. 1991. Non-Take-Up of Social Security Benefits in Europe. Journal of European Social Policy 1(1): 15-30.

Van Oorschot, Wim. 1995. Realizing Rights: A Multi-Level Approach to Non-Take-Up of Means-Tested Benefits. Aldershot: Avebury.

Van Oorschot, Wim. 1996. Modelling Non-Take-up: The Interactive Model of Multi-Level Influences and the Dynamic Model of Benefit Receipt. Pp. 7-59 in New Perspectives on the Non-Take-up of Social Security Benefits, edited by Wim Van Oorschot (TISSER Studies). Tilburg University Press. https://research.tilburguniversity.edu/en/publications/modelling-non-take-up-the-interactivemodel-of-multi-level-influe (15.03.2021).

Van Oorschot, Wim. 1998. Failing Selectivity: On the Extent and Causes of Non-Take-Up of Social Security Benefits. Pp. 101-132 in Empirical Poverty Research in a Comparative Perspective, edited by Hans-Jürgen Andreß. Aldershot: Avebury.

Van Oorschot, Wim. 2002. Targeting Welfare: On the Functions and Dysfunctions of Means-Testing in Social Policy. Pp. 171-193 in World Poverty: New Policies to Defeat an Old Enemy, edited by Peter Townsend and David Gordon. Bristol: Policy Press.

Vial, Benjamin. 2020. L'expérience du non-recours dans les parcours d'insertion des jeunes peu ou pas diplômés. Thèse de doctorat, Université Grenoble Alpes.

Warin, Philippe. 2006. Exit from and non take up of public services. A comparative analysis: France, Greece, Spain, Germany, Netherlands, Hungary. halshs-00009886.

Warin, Philippe. 2012. Le non-recours par désaccord. Welfare stigma et catégorie du non-recours. Pp. 117-136 in Usagers ou citoyens. De l'usage des catégories en action sociale et médico-sociale, edited by Marcel Jaeger. Paris: Dunod.

Warin, Philippe. 2016. Le non-recours aux politiques sociales. Grenoble: Presses Universitaires de Grenoble. 
Warin, Philippe, and Barbara Lucas. 2020. Non Take Up: A Critical Analysis Category. Working Paper 26. Grenoble: Observatoire des non-recours.

Waxman, Chaim I. 1983. The Stigma of Poverty; A Critique of Poverty Theories and Policies. New York: Pergamon Press.

Yaniv, Gideon. 1997. Welfare Fraud and Welfare Stigma. Journal of Economic Psychology 18(4): 435-451. 